\title{
Research of globalization influence to paradigm change in financial services
}

\author{
Sherzod Ishankulov ${ }^{1},{ }^{*}$, Iveta Liniņa ${ }^{2}$ \\ ${ }^{1}$ Turiba University, Faculty of Business Administration, Department of Commerce, Management \\ science, Graudu street 68, Riga, Latvia \\ ${ }^{2}$ Turiba University, Faculty of Business Administration, Department of Commerce, Graudu street 68, \\ Riga, Latvia
}

\begin{abstract}
Research background: Study of paradigm about financial services and how it changes under influence of globalization and introduction of a new player as a financial technology company or shortly Fintech. Literature and other informative sources regarding issues of innovation in financial services, impact of globalization and formation of new perspective to financial services was reviewed during the study.

Purpose of the article: The main purpose of this work is to detect and highlight the change of the concept about financial services in favor of Fintech companies supported by tendencies which are characteristic for globalization process, and how it can be beneficial for consumers and overall financial services industry.

Methods: For this research was used content analysis approach, which has advantage over other methods since it allows to extract specific data from text and other forms of information without intervention by researchers. Obtained data was encoded and applied to a model created by authors to see certain change pattern during the study of the phenomenon of financial services paradigm change.

Finding \& Value added: The findings of this research proved that globalization led to change of the paradigm about financial services. The value of this research is to provide theoretical fundamentals for application of paradigm change concept in the sphere of management science.
\end{abstract}

Key words: fintech; innovation; globalization; financial services; paradigm

JEL Classification: $G 20 ; O 33 ; M 13$

\section{Introduction}

According to Kuhn there should not be a single research in the absence of any paradigm. In his work he noted that rejecting a paradigm without simultaneously substituting with

\footnotetext{
${ }^{*}$ Corresponding author: sherzod.ishankulov@hotmail.com
} 
another one is to reject science itself. Otherwise a man of science will be seen as a carpenter who blames his tools [1].

Authors also extracted very appealing viewpoint from that work. It is said that failure of established order is the prelude to a search for a new one. The cause of that could be in so called anomalies which are not foreseen within current system of believes. Indeed, this idea can be applied to the events happened after Bretton Woods Agreement in 1944, when paper money supposed to be an equivalent of gold, but it was all changed after France requested gold for paper money from the US. That was a moment of introduction of non-gold supported money which is called fiat money [2].

In the age of digital economy, the paradigm of fiat money has been understood as never before. In aftermath of banking crisis in 2008 the belief in established financial world order has shifted. In 2009 first ever decentralized or autonomy money has been created in digital realm which is called Bitcoin. Such developments led to introduction of new players in financial services landscape - financial technology companies or shortly Fintechs.

The main problem authors will try to describe and study is existence of paradigm about financial services and how it changes under influence of globalization and Fintech companies. In other words, to see whether an idea of financial services is being used without traditional financial institutions in mind. As Kuhn noted in his work "picking up the other end of the stick" or handling similar data as before, but placing it in a new system of relations.

The main purpose of this work is to detect and highlight the change of concept about financial services in favor of Fintech companies and how it can be beneficial for consumers and overall financial services industry.

Before moving to the problem discussion it is good to note that the process of innovation in financial services industry has been tracked and studied for a while now. For example, some studies show how global investments support and initiate technology integration in finance [3].

Other study shows that new innovative finance companies gradually capture and increase market share that traditionally has been considered as banking services. Some of reasons for that are considered to be regulatory burden and high capital requirements for traditional banking companies imposed by the governments affected by financial crisis of 2007-2009. [4-5].

Historically financial services business inherited the paradigm that financial services should be with significant funds and cost of service should be tolerated by the customers. This fact was also noted in a study of opportunities that can be provided by Fintech companies [5].

However, the role of globalization as a phenomenon which includes trade, investments, exchange of technology and workforce movement was significant in formation of innovative financial companies.

New trends in technology and culture of consumption which are being set by global movement of people and information fuel up the silent and seamless change of perception of the world around. Life is being digitalized. For example, trough social media and trading of goods made the perception of life similar all over the world [6].

Digitalization of economy by financial technology companies erases the boundary between traditional banking and new wave of financial services company [5]. In other words, the concept of being served by a bank can be very well conveyed by Fintech Company.

The concept of delivering regular banking service by a non-bank innovative company seems to be so obvious that some experts in the field advice to remove regulatory barriers and let Fintechs to fully compete within banking industry [5]. 
Some expert report shows that in near perspective that financial services will change drastically. For example, consumers, businesses and society will require changes and new measure of value will appear. Moreover, the report says that banks will face absolutely new unexpected competitors, like Amazon [7].

In this way authors sorted following variables to conduct research. Those variables are: globalization; traditional financial services; and pandemia.

\section{Method}

Authors selected content analysis method [8-9]. Where qualitative data was transformed into quantitative by means of coding to increase efficiency of detecting a tendency of paradigm change. Using content analysis method, it was identified certain ideas which appeared frequently in recent studies about Fintech companies from globalization perspective. Then those key ideas were transformed to numbers and applied to graphical representation of data to see pattern of paradigm change (the pattern was developed by mathematical model) in the sphere of financial services due to globalization.

\subsection{Research sample}

For research was selected a sample of sources limited by: location, research platform Web of science and open public access researchgate.net, bis.org and ssrn.com; quality (scientific works) and year (starting from 2020 up to 10 years back). The proportion was approximately $85-90 \%$ from Web of science and the rest is from open sources mentioned above. In this research sample structure was included the parameters, where information should be from mostly scientific articles and not too old. The main criteria for selecting certain material was: concerning issues of financial services, banking, Fintech companies, globalization or financial globalization and Covid -19 pandemia. See table 1.

Table 1. Research sample structure of sources

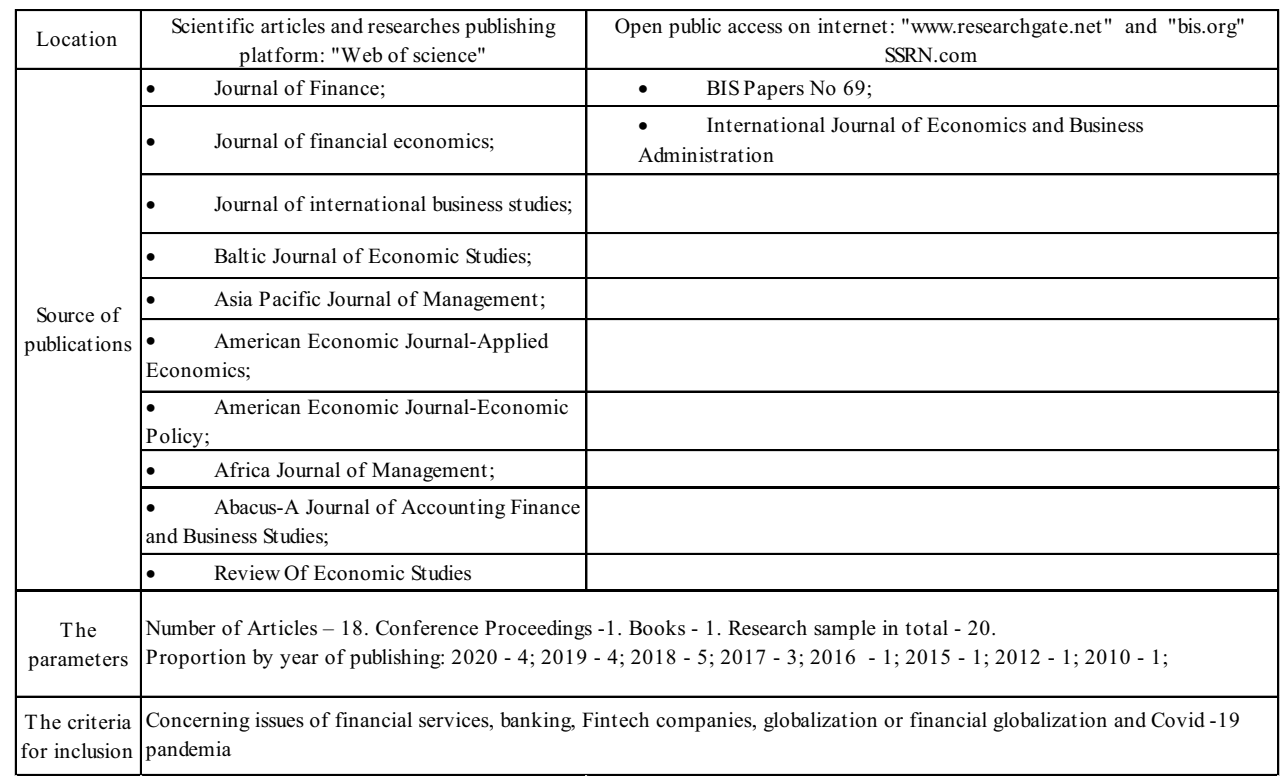

There were systematically sorted materials from articles, conference proceeding and a book. Overall it was selected 20 scientific works and put under special designation, it 
includes a designated name, full name and year of publishing for the sake of better understanding the preliminary results of the research which will be discussed later. See table 2 , the data will be fully described in results section of the article.

\subsection{Coding rules}

It was created special coding rule according to which it is necessary to calculate every specific word or words combination. Those words were derived during inspection of the materials (articles) because they have certain meaning which can be attributed to certain concepts authors were looking for. See table 4.

Authors have picked 4 main concepts for a research. As it is shown in table 4 those concepts are: globalization, traditional financial services, technology and pandemia. Since those concepts can be used to better understand and describe the research problem, which is understanding how financial services concept is being applied to new financial technology companies without having in mind traditional banking institutions, and what is the role of globalization and pandemia of Covid - 19 in it.

In order to simplify search and calculation of those words it was decided to divide each of those concepts into elements. So those elements would help better navigate path to understanding where certain word or words combination belongs.

Table 2. Designation of materials with the year of publishing

\begin{tabular}{|c|c|c|}
\hline Designation & Year & Name \\
\hline Article 1 & 2010 & Domestic Institutions and the Bypass Effect of Financial Globalization \\
\hline $\begin{array}{c}\text { Conference } \\
\text { proceedings } 2\end{array}$ & 2012 & The future of financial globalization \\
\hline Article 3 & 2015 & International Financial Integration and Cris is Contagion \\
\hline Article 4 & 2016 & Rethinking the government as innovator: Evidence from Asian firms \\
\hline Article 5 & 2017 & Globalization, Entrepreneurship And Paradox Thinking \\
\hline Article 6 & 2017 & Globalization and its negative impact on the global economy \\
\hline Article 7 & 2017 & Fintech, Regulatory Arbitrage, and the Rise of Shadow Banks \\
\hline Article 8 & 2018 & Determining the role of banks in the financing of innovative development processes of the economy \\
\hline Article 9 & 2018 & $\begin{array}{l}\text { The International Bank Lending Channel of Monetary Policy Rates and Quantitative Easing: Credit } \\
\text { Supply, Reach-for-Yield, and Real Effects }\end{array}$ \\
\hline Article 10 & 2018 & Banking the Unbanked? Evidence from Three Countries \\
\hline Article 11 & 2018 & Financial Unity of The World as an organic part of globalization \\
\hline Book 12 & 2018 & China's Belt and Road Initiative Changing the Rules of Globalization \\
\hline Article 13 & 2019 & UK's Exit Charge from the EU: Insights from Modes of Accounting \\
\hline Article 14 & 2019 & $\begin{array}{c}\text { Conceptual Framework For The Operation Of Financial Systems In The Context Of Global Structural } \\
\text { Transformations Of Business Models Of Banking }\end{array}$ \\
\hline Article 15 & 2019 & $\begin{array}{l}\text { Machine Learning and Expert Judgement: Analysing Emerging Topics in Accounting and Finance } \\
\text { Research in the Asia-Pacific }\end{array}$ \\
\hline Article 16 & 2019 & Management of Financial Institutions in Africa: Emerging Themes and Future Research Agenda \\
\hline Article 17 & 2020 & Financial inclusion and Fintech during COVID-19 crisis: Policy solutions \\
\hline Article 18 & 2020 & Dominant ideas of financial technologies In digital banking \\
\hline Article 19 & 2020 & New quality of financial institutions And business management \\
\hline Article 20 & 2020 & FinTech, Blockchain and Islamic Finance: An Extensive Literature Review \\
\hline
\end{tabular}

Each of those elements has a list of words that are selected to represent the meaning of the element and overall concept under research. For example, globalization is a concept which is separated in two elements such as "economy" and "social", while traditional financial services concept has also two elements as "traditional financial industry" and "consumer behavior element of the regular bank client"; but the concept of technology was divided into three elements such as "internet access", "financial technologies" and "regulation"; finally, the last concept is pandemia which has only one subdivision called "impact of pandemia". 
The reason of separating globalization into "economy" is to include all words which associated with economic matters which has global magnitude, while "social" is all matters associated with change of population movement and career development which is also an indicator of the concept under investigation.

Regarding the separation of the traditional financial services concept into "traditional financial industry" is to collect all words that are associated with regular banking institutions matter that has traditional industry accepted definitions, while "consumer behavior element of the regular bank client" is for all matters associated with usual bank client relationship aspects of banking business.

Next argument of separating technology into "internet access" is to estimate all words that are associated with regular digital experience of internet users, while "financial technologies" is all about change towards fully digital financial services market participants which offer wide range of digital finance advantages; but "regulation" is meant to indicate that rules are also changing to regulate new technology and theirs' users.

Finally, pandemia concept was separated into one element which would mean how often the issue of spreading coronavirus is discussed.

Then for the ease of illustration of the final results of the research each concept category was granted with code name. In case of globalization is letter " $G$ " and traditional financial services category received letter "F", while technology was named as "T", but the concept of pandemia as letter "V" as for virus.

\subsection{Algorithm of counting words}

It was created an algorithm that is for identifying and counting words is in the process of constantly inspecting each material (articles) within selected sample and match to description of the coded categories (see description in the previous subsection). Maximum limit for each category is 100 items (words). If matched word or combination of words for category concept (for example, G category) is less than 100, then other expressions (words) within one element or from next to can be added up to give total (100 words). The main task is to show the result of estimation within 100 or less. Zero result should be counted as well.

However, it is set an exception for the case of technology: if "financial technologies" element of the technology category (category $\mathrm{T}$ ) is equal to 0 , then "regulation" element should be nullified. Since regulation should be in terms of technological changes. Therefore, if no indicative words about technology then any word of regulation is irrelevant.

Final limitation is set to restrict count of words that come from titles, forwards, acknowledgements, and table of content, list of literature and source or keywords in all articles under investigation. It means all those words should be skipped because they are not active part of real research discussion.

There was introduced a simple statistical approach for the ease of analyzing derived data from 2017, 2018, 2019 and 2020 articles. It was necessary due to multiple articles within the same year. This approach is consisting of finding average or mean indicator for the cases with several publications within one year. For this purpose, was used following basic formula [10]. See equitation (1):

$$
A=\frac{1}{n} \sum_{i=1}^{n} a_{i}
$$


According to that formula (1) all the values from data set (see table 4), in this case values (total number of words per category) derived from each article, were added up and then divided to the number of articles within the one-year range. In this way data from articles within the range of 2017 (3 articles) [11-13] 2018 (5 articles) [14-18], 2019 (4 articles) [19-22] and 2020 (4 articles) [23-26] are analyzed separately from the rest publishing years. See table 3.

\section{Results}

According to derived data following preliminary results of the research was obtained after application of mean average formula (1) as it is shown in table 3. It was 0 values for the category "V" for 2017 [11-13], 2018 [14-18] and 2019 [19-22] publishing years, but in only one case in 2020 [23] all categories had their respective values.

In table 4 (see below) it was described coded categories and their elements. Where each raw represents a combined number out of elements per each category concept

In its turn elements consisted of list of words collected during inspection of the articles. Top part of the table divided into 20 columns each of them represent an article, conference preceding or a book and those designations are fully described in table 2 .

In 7 cases out of 20 inspected materials there was no mentioning about any technology relating to financial services as seen in table 4. Those are from article 3 [27], 4 [28], 5 [11], 6 [12], 8 [14], 9[15] and 13 [19]. While the issue of traditional banking institution and globalization was discussed or at least touched in all 20 articles.

Table 3. Table of coding and preliminary results for the publishing years of 2017, 2018, 2019 and 2020

\begin{tabular}{|c|c|c|c|c|}
\hline Year & 2017 & 2018 & 2019 & 2020 \\
\cline { 1 - 3 } Code & & & & \\
\hline $\mathrm{G}$ & 70.7 & 63.8 & 52.8 & 19 \\
\hline $\mathrm{F}$ & 37.3 & 84.8 & 49.8 & 39.8 \\
\hline $\mathrm{T}$ & 33.3 & 24.6 & 23 & 86.8 \\
\hline $\mathrm{V}$ & 0 & 0 & 0 & 3.8 \\
\hline
\end{tabular}

However, there was only one article dedicated to the issues combined of globalization, traditional finance, financial technology company and coronavirus or Covid-19. This was in article 17 [23] where for the first time in 20 cases mentioned the issue of global impact of Covid - 19 spreading.

\section{Discussion}

As it is shown in table 2 it was selected a sample which consist of 20 scientific works. The task was to sort out materials that would better fit for the sake of topic of the research and not so distant of publication date. The oldest publication was from 2010 [29], 2012 [30], 2015 [27], 2016 [28] and 2017 [14-18]. However, the proportion of those publication was held to minimum to not to lose actuality of the issues analyzed.

While in the table 3 above was placed the average value for 3 published articles of 2017, 5 published articles of 2018, 4 published articles of 2019 and 4 published articles of 2020 , it was all calculated and placed according to each category code. Category code and attributed letters were described in the coding rule part of Method chapter. 


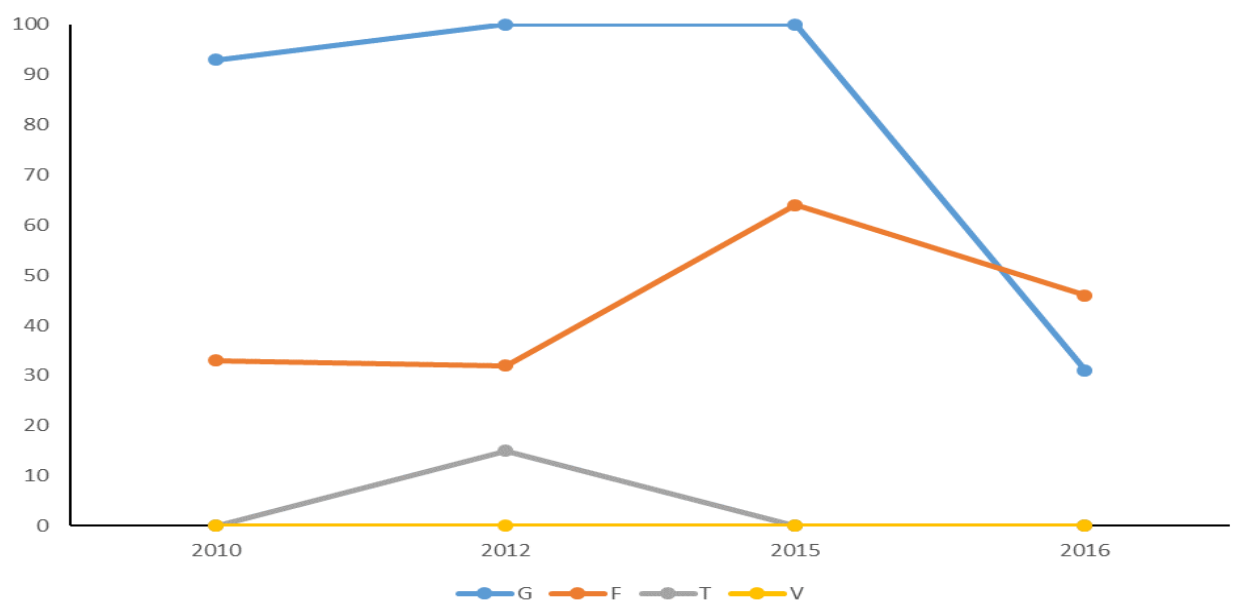

Fig. 1. Trends of discussed issues of globalization (G), traditional financial services (F), technology (T) and pandemia (V). from scientific materials published in 2010, 2012, 2015 and 2016

In table 4 there is full representation of value per each of 20 inspected article. However, in order to better understand the tendency which is actually in line with main research question of the article, it was decided to make visualization of the data for the articles of 2010 [29], 2012 [30], 2015 [27], 2016 [28] and 2017 [11-13], 2018 [14-18], 2019 [19-22], 2020 [23-26] separately by using graphical tools of the Excel program.

In this way the tendency of researched questions in some way is representation of mind set or paradigm which researchers had at that time.

Table 4. Table of coding and preliminary results of the research

\begin{tabular}{|c|c|c|c|c|c|c|c|c|c|c|c|c|c|c|c|c|c|c|c|c|c|c|}
\hline $\begin{array}{l}\text { Category } \\
\text { name } \\
\text { (code) }\end{array}$ & $\begin{array}{l}\text { Name of the } \\
\text { element }\end{array}$ & Description & $\frac{\overline{0}}{\frac{0}{E}}$ & 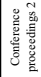 & 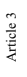 & 童 & $\frac{n}{2}$ & 品 & 产 & $\begin{array}{l}\infty \\
\frac{0}{2} \\
\frac{2}{2}\end{array}$ & 䍡 & $\frac{9}{\frac{0}{\underline{\underline{L}}}}$ & $\frac{7}{20}$ & 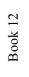 & $\frac{m}{\frac{0}{2}}$ & $\frac{d}{\frac{2}{2}}$ & $\frac{n}{\frac{0}{0}}$ & $\frac{0}{\frac{0}{2}}$ & $\frac{1}{2}$ & $\frac{\infty}{\frac{0}{0}}$ & $\frac{9}{\frac{0}{0}}$ & 竞 \\
\hline \multirow{2}{*}{ 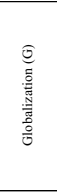 } & 产 & \begin{tabular}{|l} 
1. contain following a word or words combination: global; \\
globalisation; financial globalisation; WTO; international; \\
International trade; Export trade, free trade; trade facilitation; \\
world; cross-border; world economy; treaty; Brexit; EU, \\
Tourism, European Integration, Financial integration, foreign \\
banks, Eurozone, World bank
\end{tabular} & \multirow[t]{2}{*}{2} & \multirow[t]{2}{*}{$\stackrel{8}{\circ}$} & \multirow[t]{2}{*}{ 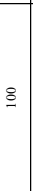 } & \multirow[t]{2}{*}{$\bar{m}$} & \multirow[t]{2}{*}{$\stackrel{8}{ }$} & \multirow[t]{2}{*}{$\stackrel{8}{9}$} & \multirow[t]{2}{*}{$\simeq$} & \multirow[t]{2}{*}{+} & \multirow[t]{2}{*}{$\stackrel{8}{9}$} & \multirow[t]{2}{*}{$\cong$} & \multirow[t]{2}{*}{$\stackrel{8}{ }$} & \multirow[t]{2}{*}{ 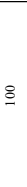 } & \multirow[t]{2}{*}{$\stackrel{8}{8}$} & \multirow[t]{2}{*}{$\stackrel{\infty}{-}$} & \multirow[t]{2}{*}{$\varnothing$} & \multirow[t]{2}{*}{8} & \multirow[t]{2}{*}{$\stackrel{m}{=}$} & \multirow[t]{2}{*}{$\bar{\lambda}$} & \multirow[t]{2}{*}{$\stackrel{\infty}{-}$} & \multirow[t]{2}{*}{$\stackrel{+}{\sim}$} \\
\hline & 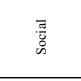 & $\begin{array}{l}\text { 2. contain following a word or words combination: } \\
\text { employment; worker; migrant worker; immigration } \\
\text { workforce; population movement; recruitment; outsource; } \\
\text { outsourcing }\end{array}$ & & & & & & & & & & & & & & & & & & & & \\
\hline \multirow{2}{*}{ 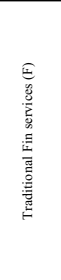 } & 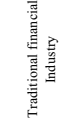 & $\begin{array}{l}\text { 1. contain following a word or words combination: traditional } \\
\text { bank; traditional bank loans; traditional financial } \\
\text { intermediation; traditional financial institutions; bank } \\
\text { branchess branch, financial institutitions; central banks, } \\
\text { financial inclusion, financial settlements, banking, financial } \\
\text { intermediaries }\end{array}$ & \multirow{2}{*}{$m$} & \multirow{2}{*}{$\approx$} & \multirow{2}{*}{ to } & \multirow[b]{2}{*}{ fo } & \multirow[b]{2}{*}{ - } & \multirow{2}{*}{$=$} & \multirow{2}{*}{ 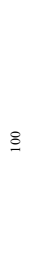 } & \multirow{2}{*}{ 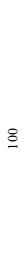 } & \multirow{2}{*}{ 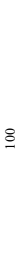 } & \multirow{2}{*}{$£$} & \multirow{2}{*}{$\overrightarrow{4}$} & & & & & & & & & \\
\hline & 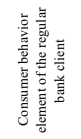 & $\begin{array}{l}\text { 2. contain following a word or words combination: deposits; } \\
\text { deposit-taking, retail deposit, financial services; bank account, } \\
\text { unbanked, transaction account, ATM }\end{array}$ & & & & & & & & & & & & $\cong$ & n & $\cong$ & - & $\infty$ & $m$ & 4 & 工 & $\infty$ \\
\hline & 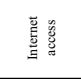 & $\begin{array}{l}\text { 1. contain follwing a word or words combination: world; } \\
\text { internet; internet communuication; online; mobile network, } \\
\text { digital services, mobile technology, mobilie application, } \\
\text { internet access, internet society }\end{array}$ & & & & & & & & & & & & & & & & & & & & \\
\hline 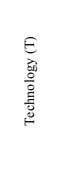 & 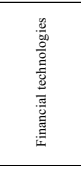 & $\begin{array}{l}\text { 2. contain following a word or words combination: } \\
\text { innovative finance, innovation in financial services; financial } \\
\text { innovation, Fintech, financial start-up, solutions, digital } \\
\text { payment systems; digital currency, mobile money accounts, } \\
\text { mobile financial services, mobile money, digital economy, } \\
\text { new/est financial institutions, digital financial institutions, } \\
\text { financial startups, financial hacathon, latest financial } \\
\text { technology, blockchain, digital ceconomy, digital business - } \\
\text { economy, cryptocurrency } \\
\end{array}$ & $m$ & $\simeq$ & o & $\circ$ & $\circ$ & o & 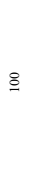 & o & o & 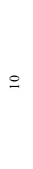 & $=$ & $\stackrel{8}{g}$ & 0 & $\infty$ & $\stackrel{i}{ }$ & $\stackrel{\infty}{n}$ & in & s & 5 & $\stackrel{8}{9}$ \\
\hline & 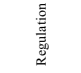 & $\begin{array}{l}\text { 1. contain following a word or words combination: regulation, } \\
\text { regulatory reforms, regulator, supervision, policy, license, } \\
\text { law, financial rules }\end{array}$ & & & & & & & & & & & & & & & & & & & & \\
\hline 爱 & 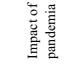 & $\begin{array}{l}\text { 1. contain following a word or words combination: Covid-19, } \\
\text { coronavirus, pandemia }\end{array}$ & o & $\circ$ & 0 & $\circ$ & o & 0 & $\circ$ & o & 0 & $\circ$ & o & 0 & 0 & o & 0 & 0 & $\because$ & 0 & $\circ$ & 0 \\
\hline
\end{tabular}


As it is clearly represented in the Fig.1 the main prevailing idea from 2010 till 2016 [2730] was globalization with blue line " $G$ " with some spike of talks about financial technology with gray line "T" in 2012 [30] and it is all in combination with the traditional finance with orange line " $F$ " or banking as we know it. The issue of globalization had lost actuality by the end of the period in 2016 [28], but the Covid-19 agenda with gold line "V" was never raised due to objective reason - it had not started to spreading till December 2019

Despite the fact that inspected only one publication per each year, the concept of financial technology and globalization was hand to hand in high priority in 2012 [30], while traditional banking institution matters dropped till new publication in 2015 [27]. As a trajectory of the grey line " $\mathrm{T}$ " was indicating to sudden increase of interest to the problem of financial innovations during the peak of interest in globalization " $G$ " line but the traditional banking topic orange line "F" was still a thing which bothered in the heads of the researchers [27-30].

Obviously a glimpse of answer to research question was demonstrated in 2012 publication [32] so visually one can see how paradigm is changing. As matter of fact how use of words referring to financial technology and globalization increased while traditional banking questions was in decline from the mentioning.

The picture transformed significantly during the period from 2017 till 2020 [11-26] as it is demonstrated on the next chart. See Fig. 2. Indeed, it is different scale as it was analyzed 16 articles during that period. The lines of technology " $T$ " and globalization " $G$ " demonstrated steady decline from 2017 all the way till 2019 [11-22]. However, the traditional financial institution agenda sky rocketed in 2018 [14-18] till joining to the decreasing team of blue and orange line in 2019 [19-22].

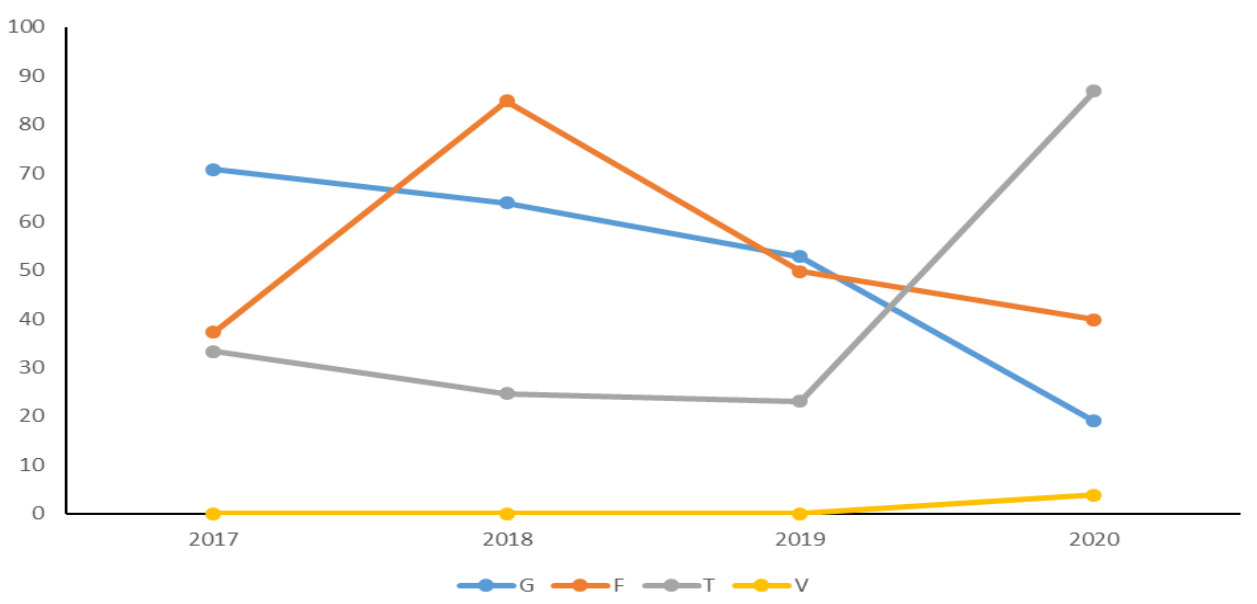

Fig. 2. Trends of discussed issues of globalization $(\mathrm{G})$, traditional financial services (F), technology (T) and pandemia (V). from scientific materials published in 2017, 2018, 2019 and 2020

Interesting tendency one could observe when two lines, globalization and technology simultaneously decreased during 3 years' period. As a matter of fact, there were 12 publications from 2017 till 2019 which independently from each other covered issues of globalization and financial innovation [11-22]. It can be one more sign of positive correlation between how globalization was triggering changes in technological developments in financial industry.

Paradigm change did project itself on the chart when financial innovation almost eclipsed the topic of traditional banking services [22-24, 26] and globalization with gradual increase of interest in coronavirus agenda [23] in 2020. However, the link between 
globalization and innovation in financial industry took negative correlation. 4 articles were analyzed which belonged to that period [23-26].

In 2020 publications [23-26] the issue of innovation in financial industry showed all time high interest than the rest of analyzed articles starting from 2010 till now. This trend displayed how research is moving toward accepting the change in terms of innovation in financial sector and how traditional banking services can be the topic of the past. Moreover, authors believe that globalization is gradually moving to the past since this phenomenon is well accepted and realized even if regular population do not notice that they left far behind the first steps towards one huge interconnected world of economy, social and technological development.

While the agenda of coronavirus is dominated publicly all over the world, but this problem was only once touched in 1 article out of 4 published in 2020 [23]. Perhaps this area is not researched properly and one should expect rise of interest in impact of this pandemia to the social and economic development all over the world in next coming new articles.

\section{Conclusion}

Authors tried to show how content analysis and some statistical approach could be beneficial in research of social and economical phenomenon. This approach could be useful in terms of modern approach to present research data visually as simple as possible especially for the people of business studies where accurate and clear results are valued highest. Overall this research could be additional to the ways how to demonstrate modern trends and why it is important to follow changes. Since for strategic business vision it is very important to collect data from all trusted sources such as scientific business articles and make calculated steps towards most possible scenario of the future developments.

\section{References}

1. Kuhn, T. S. (1970). The Structure of Scientific Revolutions. Chicago, London: University of Chicago Press Ltd.

2. Bordo, M., Simard, D., White, E. (1993). La France et le système monétaire de Bretton Woods. Revue d'Économie Financière, Programme National Persée, 26(3), 249-286.

3. Lerner, J., Schoar, A., Sokolinski, S. (2018) The globalization of angel investments: Evidence across countries. Journal of Financial Economics, 27(1), 1-20.

4. Buchak, G., Matvos, G., Piskorski, T., Seru, A. (2018) Fintech, regulatory arbitrage, and the rise of shadow banks. Journal of financial Economics, 130(3), 453-483.

5. Philippon, T. (2017). The FinTech Opportunity. BIS Working Papers 655, The 15th BIS Annual Conference: "Long-term issues for central banks". Bank for International Settlements.

6. Jaffar, A., Jaffar, A., Nurunnabi, M., Shaher, B. (2019) The Impact of Social Media on Learning Behavior for Sustainable Education: Evidence of Students from Selected Universities in Pakistan. Sustainability 11(6), Art. No. 1683

7. Sullivan, S. (2019, September 22). Banking in the age of instinct. Genpact. Retrieved from: https://www.genpact.com/instinctive-enterprise/banking

8. Gheyle, N., Jacobs, T. (2017). Content Analysis: a short overview. Internal Research Note. 
9. Burke Johnson, R., Onwuegbuzie, A.J., Turner, L.A. (2007) Toward a Definition of Mixed Methods Research. Journal of mixed Methods Research, 1(2), 112-133.

10. University of Cambridge. (2013-2020) Glossary: Arithmetic mean. Underground Mathematics. Retrieved from. https://undergroundmathematics.org/glossary /arithmetic-mean

11. Prashantham, S., Eranova, M., Couper, C., (2017) Globalization, entrepreneurship and paradox thinking. Asia Pacific Journal of Management, 1, 1-9.

12. Shopina, I., Oliinyk, O., Finaheiev, V. (2017). Globalization and its negative impact on the global economy. Baltic Journal of Economic studies, 5, 457-461.

13. Buchak, G., Matvos, G., Piskorski, T., Seru, A. (2017). Fintech, regulatory arbitrage, and the rise of shadow banks. Journal of Financial Economics, 3, 453-483.

14. Zavadska, D. (2018). Determining the role of banks in the financing of innovative development processes of the economy. Baltic Journal of Economic studies, 3, 68-73.

15. Morais, B., Peydro, J.L., Roldan-Pena, J., Ruiz-Ortega, C., (2018) The International Bank Lending Channel of Monetary Policy Rates and QE: Credit Supply, Reach-forYield, and Real Effects. Journal of Finance, 1, 55-90.

16. Dupas, P., Karlan, D., Robinson, J., Ubfal, D. (2018). Banking the Unbanked? Evidence from Three Countries. American Economic Journal - Applied Economics, 2, 257-297.

17. Honcharenko, I., Servatynska, I. (2018). Financial unity of the world as an organic part of globalization. Baltic Journal of Economic Studies, 2, 53-57.

18. Buckley, P.J. (2018). China's belt and road initiative: Changing the rules of globalization. Journal of International Business Studies, 2, 279-281.

19. Heald, D., Wright, I. (2019). The UK's Exit Charge from the EU: Insights from Modes of Accounting. ABACUS - A Journal of Accounting Finance and Business Studies, 3, 557-581.

20. Melnyk, T., Melnychenko, S., Reznikova, N. (2019). The conceptual framework for the operation of financial systems in the context of global structural transformations of business models of banking. Baltic Journal of economic Studies, 4, 148-154.

21. Cai, C.W., Linnenluecke, M.K., Marrone, M., Singh, A.K. (2019). Machine Learning and Expert Judgement: Analyzing Emerging Topics in Accounting and Finance Research in the Asia-Pacific. ABACUS - A Journal of Accounting Finance and Business Studies, 4, 709-733

22. Adeleye, I., Debrah, Y.A., Nachum, L. (2019). Management of financial institutions in Africa: Emerging themes and future research agenda. Africa Journal of Management, 3, 215-230.

23. Peterson K O. (2020). Financial Inclusion and Fintech during COVID-19 Crisis: Policy Solutions, SSRN Electronic Journal.

24. Melnychenko, S., Volosovych, S., Baraniuk, Y. (2020). Dominant ideas of financial technologies in digital banking. Baltic journal of Economic studies, 1, 92-99.

25. Kraus, N., Kraus, K., Osetskyi, V. (2020). New quality of financial institutions and business management. Baltic Journal of Economic studies, 1, 59-66

26. Rabbani M. R. Khan. Sh., Thalassinos I. E. (2020). FinTech, Blockchain and Islamic Finance: An Extensive Literature Review. International Journal of Economics and Business Administration, 2, 65-86.

27. Devereux, M.B., Yu, CH. (2015). International Financial Integration and Crisis Contagion. Review of Economic Studies, 3, 1174-1212. 
28. Poczter, S. (2016). Rethinking the government as innovator: Evidence from Asian firms. Asia Pacific Journal of Management, 2, 367-397.

29. Ju, J.D., Wei, S.J. (2010). Domestic Institutions and the Bypass Effect of Financial Globalization. American Economic Journal - Economic Policy, 2, 173-204.

30. Lane P., Taylor A., Gourinchas P.O., Jeanne O., Song Shin H. (2012). The future of financial globalisation, BIS Working Papers, 69. 